\title{
Toksisitas Oil Sludge Hasil Fitoremediasi Long Term Pada Hitologis Hati Mencit (Mus Musculus)
}

\author{
Nana Media*, Nia Rossiana, Desak Made Malini \\ Departemen Biologi, Fakultas Matematika dan Ilmu Pengetahuan Alam, Universitas Padjadjaran. Jl. Raya \\ Bandung-Sumedang Km 21 Jatinangor, Sumedang 45363, Jawa Barat. \\ Email: nana.medi4@gmail.com
}
APA Citation: Media, N., Rossiana, N., \& Malini, D.M. (2020). Toksisitas Oil Sludge Hasil Fitoremediasi Long Term Pada Hitologis Hati Mencit (Mus Musculus), Quagga: Jurnal Pendidikan dan Biologi, 12(2), 130-136. doi: 10.25134/quagga.v12i2.2621.

Received: 05-02-2020

Accepted: 27-05-2020

Published: 01-07-2020

\begin{abstract}
Abstrak: Lumpur minyak bumi atau Oil sludge merupakan limbah yang berasal dari kegiatan pengolahan, penyaluran dan penampungan minyak bumi, yang dapat mencemari lingkungan dan membahayakan kesehatan manusia. Salah satu upaya penanganan limbah oil sludge adalah dengan metode bioremediasi, yang dapat dilakukan oleh mikroorganisme dan menggunakan tumbuhan (fitoremediasi). Penelitian Hasil fitoremediasi oil sludge dengan menggunakan konsorsium bakteri (Bacillus sphaericus, Pseudomonas sp) dan sengon (Paraserianthes falcataria) selama 30 bulan dilakukan untuk mengetahui tingkat toksisitas yang terjadi dengan menggunakan mencit (Mus musculus l) betina sebagai hewan uji. Tujuan dari penelitian ini adalah untuk mendapatkan nilai LD50 dan toksisitas dari ekstrak medium Oil Sludge pertumbuhan sengon yang telah di fitoremediasi dan mengetahui toksisitas terhadap histologis hati mencit. Pengujian toksisitas akut mengacu pada OECD 425 tahun 2001 dengan batas bawah dosis sebesar 5000 mg/kg BB. Substansi uji diberikan secara oral pada hewan uji berupa mencit (Mus musculus l) betina dengan dosis tunggal 5.500, 6.500, 7.300, 8.200, 9.100, 1.000, 12.000, 12.600 dan $17000 \mathrm{mg} / \mathrm{kg}$ BB. Parameter pengamatan meliputi gejala toksisitas, perubahan berat badan, dan jumlah hewan uji yang mati diamati selama 14 hari, sedangkan histopatologi pada organ hati diamati pada hewan uji yang mati dan yang hidup setelah periode uji selesai. Hasil penelitian menunjukkan bahwa perlakuan ekstrak medium oil sludge sengon hasil fitoremediasi 30 bulan menimbulkan gejala toksisitas dan penurunan berat badan. Berdasarkan hasil analisis Probit, nilai LD50 dari ekstrak medium oil sludge hasil fitoremediasi 30 bulan terhadap mencit diprediksi mencapai $16.982 \mathrm{mg} / \mathrm{kg} \mathrm{BB}$, sehingga termasuk ke dalam kategori praktis tidak toksik.
\end{abstract}

Kata kunci: Oil sludge, fitoremediasi, uji toksisitas, Mencit (Mus musculus).

\begin{abstract}
Petroleum mud or oil sludge is a waste originating from cultivation, distribution, and reception activities that could contaminate the environment as well as endanger human health. One of the handling efforts of oil sludge was by using bioremediation. Bioremediation not only could be done by microorganisms but also could be used by using plants (phytoremediation). The remediation result of oil sludge by using bacterial consortium for 30 months (Bacillus sphaericus, Pseudomonas sp.) And sengon (Paraserianthes falcataria) further research must be carried out to find out the level of toxicity, in this case, the Wistar mice (Mus musculus l) used as the test animal. The objectives of the research were to obtain LD50 value from sengon growth that had been phytoremediation for 30 months and also to discover toxicity influence against liver histology of the mice. Acute toxicity testing agreed to OECD 425 of 2001 with a lower dose limit of $5000 \mathrm{mg} / \mathrm{kg}$ body weight. The test substance is administered orally to test animals in the form of female mice (Mus musculus l) with a single dose of 5,500, 6,500, 7,300, 8,200, 9,100, 1,000, 12,000, 12,600 and $17000 \mathrm{mg} / \mathrm{kg} \mathrm{BW}$. Observation parameters including symptoms of toxicity, changes in body weight, and the number of dead test animals were observed for 14 days, while histopathology in the liver was observed in test animals that died and lived after the test period was finished. The results showed that the treatment of Sengon medium sludge oil sludge extract 30 months resulted in symptoms of toxicity and weight loss. Based on the results of the Probit analysis, the LD50 value of the 30-month phytoremediation medium sludge extract against mice is predicted to reach $16,982 \mathrm{mg} / \mathrm{kg} \mathrm{body}$ weight, so that it is included in the practically non-toxic category.
\end{abstract}

Keywords: oil sludge, phytoremediation, toxicity acute test, Mice (Mus musculus l) 


\section{PENDAHULUAN}

Lumpur minyak bumi atau Oil sludge merupakan limbah yang berasal dari kegiatan pengolahan, penyaluran dan penampungan minyak bumi. Salah satu industri yang menghasilkan Oil sludge adalah Pertamina EP Balongan. Salah satu upaya penanganan limbah oil sludge adalah menggunakan metode bioremediasi (Kepmen LH Nomor 128, 2003). Bioremediasi merupakan upaya pemulihan lahan yang telah tercemar dengan memanfaatkan kemampuan mikrorganisma dalam mendegradasi substansi organik dan anorganik (Pala dkk., 2006). Upaya untuk melakukan pegelolaan limbah minyak tidak hanya dapat dilakukan dengan bioremediasi menggunakan mikroorganisme, tetapi dapat dilakukan dengan menggunakan tanaman (fitoremediasi).

Hasil uji tosisitas akut Fitoremediasi Oil sludge selama 14,5 bulan terhadap mencit menunjukkan bahwa nilai LD50 berada pada rentang dosis $9.785,184 \mathrm{mg} / \mathrm{kg}$ BB nilai tersebut termasuk dalam kategori toksik ringan $(5.000-$ 15.000), kandungan logam berat yang terdeteksi $\mathrm{Pb} 6$ ppm, Ni 3,64, Cd 0,01, Cr 3,34, Hg 267 ppb (Rossiana, dkk., 2017).

Tanaman yang digunakan dalam proses fitoremediasi adalah tanaman sengon karena memiliki kemampuan untuk mengendapkan kontaminan sehingga kontaminan lebih mudah di degradasi oleh mikroorganisme, selain itu syarat dalam proses fitoremediasi adalah tanaman yang bukan untuk pakan baik hewan maupun manusia (Rossiana, dkk., 2018). Beberapa laporan telah mengklasifikasikan genus Pseudomonas dan Bacillus sebagai biopengemulsi yang memiliki potensi untuk meningkatkan kemampuan sengon dalam mendegradasi oil sludge (Yu dkk., 2007).

Untuk mengetahui tingkat penurunan toksisitas yang terjadi perlu dilakukan penelitian lanjutan mengenai toksisitas akut oil sludge hasil fitoremediasi selma 30 bulan. Pada uji toksisita akut diperlukan juga uji histologis pada hewan uji untuk mendeteksi adanya kerusakan pada organ tertentu akibat pemberian perlakuan (Liu, 2010). Kandungan dari hidrokarbon antara lain benzene, toluene, ethylbenzene, xylenes, dan logam berat seperti timbal $(\mathrm{Pb})$ pada oil sludge merupakan limbah B3 yang termasuk dalam karakteristik beracun, (PT Pertamina, 2001).

\section{METODOLOGI PENELITIAN Metodologi Penelitian}

Penelitian ini menggunakan metode eksperimental dengan rancangan acak lengkap (RAL), di lakukan di labolatorim biosistem hewan unpad dengan mengacu pada pedoman OECD (Organisation for Economic Cooperation and Develotment) 423 Guideline for Testing of Chemicals -Acure Toxicity Class OECD (2001). Uji toksisitas akut Oil sludge ini diawali dengan uji pendahuluan limit test dan dilanjutkan dengan uji main test, Subjek penelitian dibagi menjadi kelompok kontrol dan kelompok perlakuan. Analisa logam berat dengan metode Atomic Absorption Spectrophotometer (AAS) dilakukan di Laboratorium Pusat Penelitian dan Pengembangan Geologi Kelautan (P3GL) Bandung.

\section{Bahan penelitian}

Bahan-bahan yang digunakan dalam penelitian ini adalah hewan uji, bahan uji, serta bahan kimia. Hewan uji yakni Mencit betina umur 2 bulan dengan bobot \pm 28 gram Bahan uji adalah ekstak medium pertumbuhan sengon (Paraserianthes falcataria) yang telah di fitoremediasi selama

30 bulan menggunakan konsorsium bakteri (Bacillus sphaericus, Pseudomonas sp.) yang merupakan hasil dari penelitian ahli sebelumnya. Zat kimia yang digunakan meliputi akuades, etanol 96\%, etanol 100\%, $\mathrm{NaCl}$ Fisiologis $(0,9 \%)$, entelan, eosin, hematoksilin, larutan tween 80 (Bratachem), paraffin pastiles (Merck), spirtus, dan xylene (Bratachem).

\section{Uji Toksisitas Akut}

Uji toksisitas akut terbagi menjadi dua tahapan, yaitu tahap limit test dan main test. Uji pendahuluan ini dilakukan untuk menentukan dosis batas bawah dari oil sludge yang akan digunakan untuk penentuan dosis Main Test. Limit test menggunakan hewan uji Mencit (Mus musculus $l$ ) betina yang dipilih secara acak dan dibagi ke dalam dua kelompok perlakuan. yaitu kelompok dengan pemberian dosis 2.000 dan $5.000 \mathrm{mg} / \mathrm{kg} \mathrm{BB}$ masing-masing 4 ekor mencit. Pengamatan dilakukan selama 48 Jam dengan parameter jumlah mortalitas mencit (OECD, 2008). Hasil uji limi test dosis $5.000 \mathrm{mg} / \mathrm{kg} \mathrm{BB}$ menujuka tidak ada kematian hewan uji, 
sehingga yang digunakan untuk uji Maint Test lebih tinggi.

Uji Maint Test dilakukan untuk menentukan nilai LD50 dari ekstrak medium oil sludge hasil fitoremediasi 30 bulan dengan dosis bertingkat mulai dari $5.500 \mathrm{mg} / \mathrm{kg} \mathrm{BB}$ dan jika tidak ditemukan lebih dari tiga ekor hewan uji yang mati maka dosis ditingkatkan menurut Tabel pedoman prognosis pada OECD 423 (2001) hingga ditemukan tiga atau lebih hewan uji yang mati dari setiap dosis perlakuan. Pada penelitian ini, dosis yang digunakan untuk uji Maint test adalah 0, $5.500,6.500,7.300,8.200,9.100,1.000$, $12.000,12.600$ dan $17000 \mathrm{mg} / \mathrm{kg}$ BB. Masingmasing perlakuan terdiri atas empat ekor hewan uji.

Hewan uji diamati secara individual setidaknya satu kali selama 40 menit pertama dan berikutnya hingga 24 jam dengan pengamatan khusus dilakukan pada 5 jam pertama pasca perlakuan. Selanjutnya, pengamatan gejala toksisitas dan perubahan berat badan juga ditimbang hari ke-7 dan pada hari ke-14. Pada hari ke- 15, hewan uji yang selamat dikorbankan untuk diambil organ hatinya, kemudian difiksasi dalam larutan Boiun. Sediaan histologis hati dilakukan dengan metode paraffin dan pewarnaan Hematoksilin-Eosin (Humason 1979).

\section{Analisis Data}

Nilai Lethal Dose 50 (LD50) dianalisis menggunakan analisis probit (probability integral transformation). Analisis data kuantitatif dari perubahan berat badan, dilakukan secara statistik parametrik menggunakan Analisis Varians (ANAVA) satu arah dengan taraf kepercayaan $95 \%$ jika terdapat pengaruh yang nyata maka dilanjutkan dengan uji Duncan.

Kerusakan histopatologis yang diamati pada hati meliputi persentase sel hepatosit yang mengalami nekrosis dan diameter vena sentralis. Pembacaan dilakukan menggunakan mikroskop cahaya dengan perbesaran 400x. Pada organ hati sebanyak 1000 sel hepatosit dibaca pada tiap preparat dan kemudian dihitung kerusakan hati yang terjadi pada setiap 5 lapang pandang, semua data dianalisis menggunakan program SPSS versi 17.0.

\section{HASIL DAN PEMBAHASAN}

Toksisitas LD50 Main Test Oil Sludge Hasil Fitoremediasi Long Term Pada Hitologis Hati Mencit (mus musculus)

Hasil uji limit test tidak menujukan adanya kematian mencit pada dosis 2.000 dan 5.000 $\mathrm{mg} / \mathrm{kg} \mathrm{BB}$. Oleh sebab itu, dosis perlakuan yang digunakan pada maint test lebih dari 5.000 $\mathrm{mg} / \mathrm{kg}$ BB sesuai dengan Tabel prognosis panduan OECD (2001).

Tabel 1. Uji Hasil Main Test Toksisitas Oil Sludge Hasil Fitoremediasi Long Term Pada Hitologis Hati Mencit (mus musculus)

\begin{tabular}{ccc}
\hline $\begin{array}{c}\text { Dosis Ekstrak } \\
\text { Oil sludge } \\
\text { (mg/kg BB) }\end{array}$ & $\begin{array}{c}\text { Jumlah } \\
\text { Total } \\
\text { Mencit yang } \\
\text { Diuji (ekor) }\end{array}$ & $\begin{array}{c}\text { Jumlah } \\
\text { Mencit } \\
\text { yang } \\
\text { Mati } \\
\text { (ekor) }\end{array}$ \\
\hline 0 (Kontrol) & 4 & 0 \\
5.500 & 4 & 0 \\
6.500 & 4 & 0 \\
7.300 & 4 & 0 \\
8.200 & 4 & 0 \\
9.100 & 4 & 0 \\
10.000 & 4 & 0 \\
12.000 & 4 & 0 \\
12.600 & 4 & 1 \\
17.000 & 4 & 2 \\
\hline
\end{tabular}

Hasil dari uji Maint Test menunjukkan bahwa perlakuan ekstrak medium oil sludge hasil fitoremediasi long Term dengan dosis 0-12.000 $\mathrm{mg} / \mathrm{kg}$ BB tidak menyebabkan kematian pada hewan uji, sedangkan perlakuan dengan dosis 12.600 dan $17.000 \mathrm{mg} / \mathrm{kb}$ BB secara berturutturut menyebabkan kematian hewan uji sebanyak satu dan dua ekor. Dengan demikian, nilai LD50 diperkirakan berada pada rentang dosis 12.600 dan $17.000 \mathrm{mg} / \mathrm{kg} \quad$ BB. Berdasarkan hasil analisis Probit, nilai LD50 sebesar $16.982 \mathrm{mg} / \mathrm{kg}$ BB. Dalam klasifikasi toksisitas menurut $\mathrm{Lu}$ (2002), nilai tersebut termasuk ke dalam kategori praktis tidak toksik (>15000 mg/kg BB).

Perlakuan peberian ekstrak medium oil sludge sengon hasil fitoremediasi 30 bulan terhadap mencit hingga dosis $12.000 \mathrm{mg} / \mathrm{kg} \mathrm{BB}$ tidak menyebabkan kematian, juga tidak menimbulkan gejala toksisitas seperti perubahan perilaku dan fisiologis (kejang, batuk, dan penerunuan aktivitas motorik) selama periode pengamatan, yaitu 4 jam hingga 
14 hari pasca pemberian dosis, perlakuan yang diberikan juga tidak menyababkan perbedaan berat badan mencit apabila dibandingkan dengan kontrol.

Tabel 2. Hasil Pengukuran Berat Badan Ekstrak Medium Oil Sludge Hasil Fitoremediasi Long Term Pada Hitologis Hati Mencit (mus musculus) Selama Pengujian LD L $_{50}$

\begin{tabular}{cccccc}
\hline \multirow{2}{*}{ DOSIS } & \multirow{2}{*}{$\begin{array}{l}\text { Jumlah } \\
\text { Mencit }\end{array}$} & \multicolumn{2}{c}{ Rata-Rata Berat Badan (gr) } & \multirow{2}{*}{$\begin{array}{c}\Delta \text { Berat } \\
\text { Badan } \\
\text { (gr) }\end{array}$} \\
\hline Kontrol & 4 & $28,26 \pm 1,7$ & $29,53 \pm 4,6$ & $34,13 \pm 5,8$ & $5,50 \pm 2,9^{\mathrm{d}}$ \\
\hline $\mathbf{5 . 0 0 0}$ & 4 & $28,70 \pm 1,1$ & $29,80 \pm 4,3$ & $34,13 \pm 5,4$ & $4,52 \pm 2,4^{\text {cd }}$ \\
\hline $\mathbf{5 . 5 0 0}$ & 4 & $27,96 \pm 1,4$ & $29,33 \pm 2,8$ & $32,13 \pm 4,7$ & $4,22 \pm 2,1^{\text {cd }}$ \\
\hline $\mathbf{6 . 5 0 0}$ & 4 & $28,06 \pm 1,4$ & $29,47 \pm 4,7$ & $33,53 \pm 5,7$ & $4,97 \pm 2,5^{\text {cd }}$ \\
\hline $\mathbf{7 . 3 0 0}$ & 4 & $28,00 \pm 2,5$ & $30,43 \pm 2,7$ & $33,00 \pm 5,1$ & $4,93 \pm 2,7^{\text {cd }}$ \\
\hline $\mathbf{8 . 2 0 0}$ & 4 & $29,63 \pm 0,5$ & $29,13 \pm 3,1$ & $32,23 \pm 2,6$ & $3,05 \pm 1,8^{\text {cd }}$ \\
\hline $\mathbf{9 . 1 0 0}$ & 4 & $29,76 \pm 2,4$ & $32,17 \pm 1,9$ & $34,06 \pm 4,3$ & $3,95 \pm 2,4^{\mathrm{b}}$ \\
\hline $\mathbf{1 0 . 0 0 0}$ & 4 & $29,90 \pm 0,9$ & $30,80 \pm 2,7$ & $33,16 \pm 3,7$ & $3,44 \pm 1,7^{\mathrm{b}}$ \\
\hline $\mathbf{1 2 . 0 0 0}$ & 4 & $28,23 \pm 0,6$ & $28,30 \pm 2,3$ & $30,60 \pm 2,7$ & $2,90 \pm 1,7^{\mathrm{a}}$ \\
\hline
\end{tabular}

Pada Tabel 2 menunjukan bahwa berat badan mencit dari kelompok dosis 5.000 hingga $10.000 \mathrm{mg} / \mathrm{kg}$ BB mengalami penurunan namun tidak berbeda nyata dengan kontrol, sedangkan untuk kelompok perlakuan $12.000 \mathrm{mg} / \mathrm{kg}$ BB mengalami penurunan yang signifikan dibandingkan dengan kelompok kontrol $(\mathrm{P}<0,05)$. Hal ini disebabkan pemberian dosis yang cukup tinggi memengaruhi sistem pencernaan dan menganggu proses absorpsi pada saluran pencernaan. Pada saluran pencernaan terdapat usus halus yang dapat bergerak karena adanya aktivitas otot usus halus yang mengakibatkan terjadinya gerakan peristaltik. Peristaltik berfungsi untuk menggerakan kimus sepanjang usus dan meningkatkan pergeseran kimus dengan permukaan mukosa usus, sehingga kimus dapat dicerna dan nutrient dapat diabsorpsi (Thomas, 2003; Cunningham, 2002).

Gerakan peristaltik usus halus dapat berubah oleh pengaruh virus, bakteri, parasit dan toksin. Radang usus halus dapat menyebabkan penurunan konduksi transmural. Jika konduksi transmural turun, maka gerak peristaltik usus halus akan turun. Apabila usus halus mengalami trauma, terdapat pengurangan gerakan usus halus disebabkan karena hambatan langsung pada otot polosnya (Berkes dkk., 2003; Cunningham, 2002).

Bahan kimia dari oil sludge termasuk kategori B3 yang dapat merusak kesehatan. Menurut Manahan, (2003) bahan kimia dapat menghancurkan atau merusak permukaan internal dari traktus gastrointestinal dan memperlambat atau menghentikan gerakan peristaltik usus, sehingga terjadi penyerapan toksikan itu sendiri dan berdampak pada berkurangnya nafsu makan. Berkurangnya nafsu makan yang menyebabkan hewan uji kurangnya masukan asupan gizi berpengaruh terhadap pertumbuhan dan status gizi, hal ini tercermin perubahan berat badan (BB). Adapun makanan yang masuk ke dalam tubuh mencit akan menyebar ke seluruh tubuhnya yang dibawa oleh plasma darah. Menurut Lu (1995), setelah suatu zat kimia memasuki darah, zat tersebut akan didistribusikan dengan cepat ke seluruh bagian tubuh.

\section{Kandungan Logam Berta Ekstrak Medium Oil Sludge Hasil Fitoremediasi Long Term Pada Hitologis Hati Mencit (mus musculus) Hasil uji Atomic Absorption} Spectrophotometer (AAS) yang telah dilakukan, menunjukan bahwa oil sludge yang di fitoremediasi selama 30 bulan mengandung logam seperti Timbal (Pb), Nikel (Ni), Kadium (Cd), Kromium (Cr), dan Merkuri (Hg), hasil uji yang telah dilakuakan ditampilakan pada Tabel 3.

Tabel 3. Hasil Analisis Logam Berat ekstrak medium oil sludge Hasil Fitoremediasi Long

Term Pada Hitologis Hati Mencit (mus musculus)

\begin{tabular}{lcc}
\hline \multicolumn{3}{c}{ Atomic Absorption Spectrophotometer (AAS) } \\
Parameter & $\begin{array}{c}\text { Baku Mutu } \\
\text { PP No 128 } \\
\text { Tahun 2003 } \\
(\mathbf{p p m})\end{array}$ & $\begin{array}{c}\text { Nilai analisis } \\
\text { ekstrak medium } \\
\text { oil sludge 30 } \\
\text { bulan (ppm) }\end{array}$ \\
\hline Timbal (Pb) & 5 & 1,42 \\
\hline Nikel (Ni) & 3,5 & 1,45 \\
\hline Kadium $(\mathbf{C d})$ & 1 & 0,27 \\
\hline Kromium $(\mathbf{C r})$ & 5 & 1,95 \\
\hline Merkuri $(\mathbf{H g})$ & 0,2 & 0,65 \\
\hline
\end{tabular}


Pada Tabel 3 dapat dilihat bahwa kandungan logam $\mathrm{Pb}, \mathrm{Ni}, \mathrm{Cd}$, dan $\mathrm{Cr}$ pada ekstrak medium oil sludge hasil fitoremediasi 30 bulan terlihat lebih rendah dari batas baku mutu yang ditentukan oleh PP. No 128 Tahun 2003. Sedangkan kandungan Merkuri $(\mathrm{Hg})$ pada ekstrak medium oil sludge hasil fitoremediasi 30 bulan lebih tinggi apabila dibandingkan dengan baku mutu.

Peningkatan kandungan $\mathrm{Hg}$ seiring bertambahnya waktu fitoremediasi dapat disebabkan mengalami transformasi ketika terdeposit dalam tanah dengan bantuan mikroorganisme menjadi metil merkuri $(\mathrm{MeHg})$, $\mathrm{MeHg}$ merupakan jenis $\mathrm{Hg}$ yang dibentuk oleh bakteri ataupun proses alamiah (Grandjean dkk., 2010). Menurut Abdullah, dkk.,(2018) MeHg sangat reaktif dan mempunyai mobilitas tinggi dibandingkan $\mathrm{Hg}^{0}$ dan $\mathrm{Hg}^{2+}$. Menurut Nurdin, (2012) keracunan metil merkuri menyebabkan efek pada gastrointestinal dan dalam kondisi tertentu dapat bereaksi dengan metana yang berasal dari dekomposisi senyawa organik sehingga membentuk metil merkuri yang bersifat toksis. Dengan demikian, dapat dikatakan bahwa fitoremediasi selama 30 bulan berdasarkan hasil analilsis AAS belum mampu mendegradasi kandungan $\mathrm{Hg}$, sehingga belum aman bagi lingkungan.

\section{Pengamatan Histologis Organ Hati Mencit (Mus musculus $l$ )}

Pengamatan sediaan histologis organ hati dilakukan untuk mengetahui toksisitas akut ekstrak medium oil sludge terhadap histopatologis organ hati hewan uji, dan hasilnya disajikan pada Gambar 1. berdasarkan hasil pengamatan secara histologis, mencit kontrol (hanya diberi pelarut tuin 80) menunjukan kondisi struktur hati normal dengan ciri-ciri hepatosit berbentuk polihendral dengan sitoplasama homogen berwarna merah dan nucleus berbentuk bulat atau oval berwarna ungu (Gambar 1.A).

Pada hepatosit normal dapat teramati satu atau dua nukleus (binukleat). Hal ini sesuai dengan kriteria hepatosit normal menurut Bavelander dan Ramaley (1988). Hepatosit juga berbatasan dengan sinusoid yang berisi darah dan tersusun radial terhadap vena sentralis (Dellmann dan Brown, 1992). Vena sentralis memiliki ciri-ciri batas dinding tunika intima jelas dan utuh yang tersusun atas sel endothelium dan sel kupfer. Hal ini sesuai dengan kriteria lobules hati normal menurut Wisse, et al., (1996).
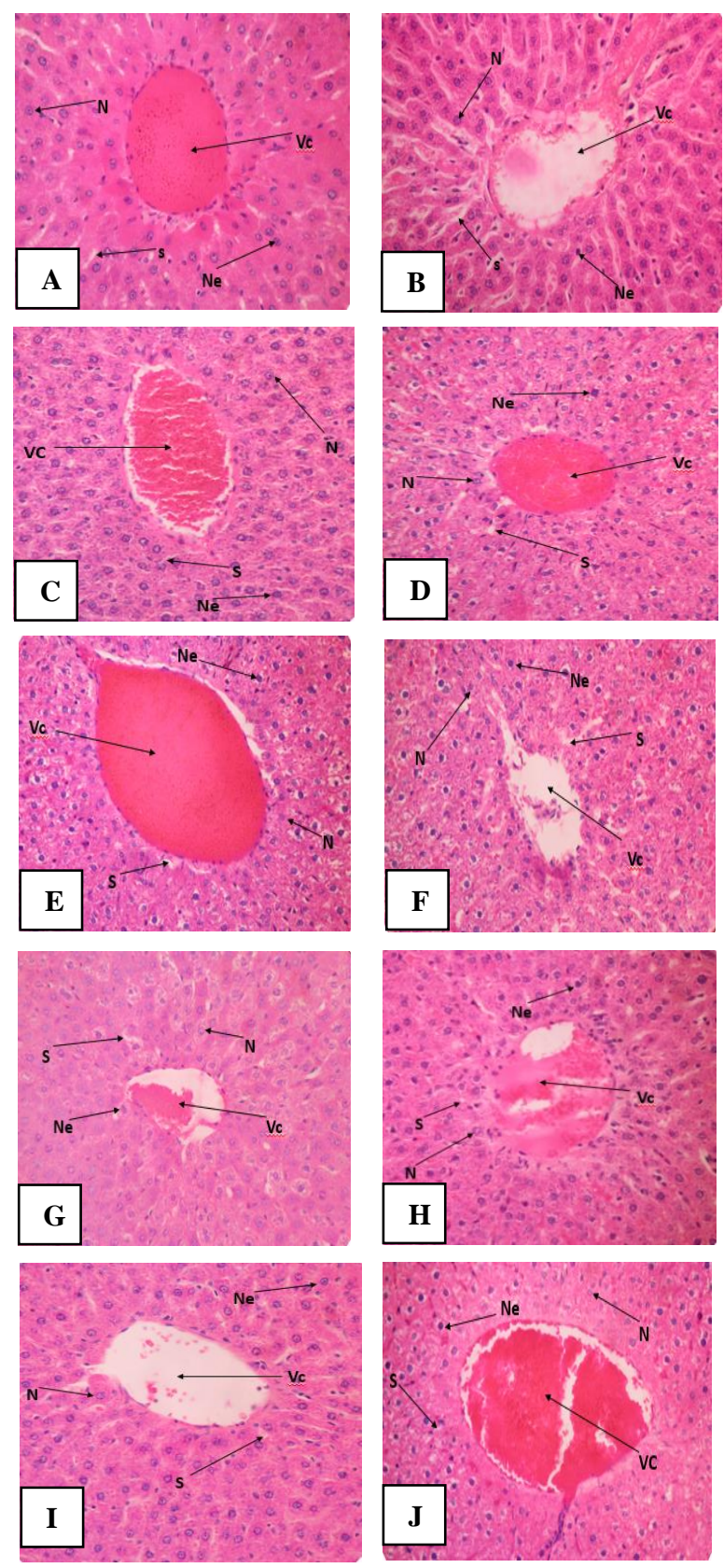

Gambar 1. Sayatan Melintang Histologis Hati Mencit Pewarnan Hematoksilin-Eosin (400x) Ket: A) Kontrol; B) $5000 \mathrm{mg} / \mathrm{kg} \mathrm{BB}$; C) $5500 \mathrm{mg} / \mathrm{kg} \mathrm{BB}$; D) $6500 \mathrm{mg} / \mathrm{kg} \mathrm{BB}$; E) $7300 \mathrm{mg} / \mathrm{kg} \mathrm{BB}$; F) 8200 ; G) $9100 \mathrm{mg} / \mathrm{kg} \mathrm{BB}$; H) $10000 \mathrm{mg} / \mathrm{kg}$ BB; I) 12000 $\mathrm{mg} / \mathrm{kg} \mathrm{BB} ; \mathrm{J}$ ) $12600 \mathrm{mg} / \mathrm{kg} \mathrm{BB}$. (Vc) Vena Sentralis, (S) Sinusoid, (N) Hepatosit normal, (Ne) Hepatosit Nekrosis.

Menurut Winarsih, dkk., (2012) piknotik bersifat reversible yang artinya sel dapat kembali normal apabila zat toksik telah hilang, namun bila paparan toksikan terlalu lama dengan 
konsentrasi tinggi akan menyebabkan kematian sel secara nekrosis yang bersifat irreversible (sel tidak dapat kembali normal). Kerusakankerusakan teramati pada sediaan histologis hati ini diduga disebabkan oleh senyawa toksik yang berasal dari perlakuan pemberian ekstrak medium oil sludge secara oral.

Berdasarkan Tabel 4 diketahui bahwa terdapat peningkatan persentasi hepatosit nekrosis dan diameter Vena Sentralis seiring dengan peningkatan dosis. Berdasarkan uji ANAVA, pemberian ekstrak medium oil sludge hasil fitoremediasi 30 bulan terhadap mencit berpengaruh terhadap peningkatan diameter vena sentralis dan persentasi nekrosis hepatosit $(\mathrm{P}<0,05)$ (Lampiran 2 dan 3) hal ini diduga disebabkan oleh peningkatan kadar zat toksik yang berkaitan dengan semakin tingginya dosis ekstrak medium oil sludge.

Tabel 4. Hasil Pengukuran Parameter Histologis Organ Hati

\begin{tabular}{ccc}
\hline $\begin{array}{c}\text { Ekstrak } \\
\text { Oil } \\
\text { Sludge } \\
(\mathbf{m g} / \mathbf{k g} \\
\text { BB })\end{array}$ & $\begin{array}{c}\text { Rataan } \\
\text { Diameter Vena } \\
\text { Sentralis } \\
(\mathrm{x} \pm \mathrm{SD})(\mu \mathrm{m})\end{array}$ & $\begin{array}{c}\text { Rataan Persentase } \\
\text { Hepatosit } \\
\text { Nekrosis } \\
(\mathrm{x} \pm \mathrm{SD})(\%)\end{array}$ \\
\hline Kontrol & $25,86 \pm 2,4^{\mathrm{d}}$ & $53,05 \pm 6^{\mathrm{g}}$ \\
\hline $\mathbf{5 . 0 0 0}$ & $33,50 \pm 4,1^{\mathrm{bc}}$ & $65,5 \pm 5,7^{\mathrm{ef}}$ \\
\hline $\mathbf{5 . 5 0 0}$ & $31,83 \pm 2,9^{\mathrm{ab}}$ & $59,5 \pm 3,1^{\mathrm{fg}}$ \\
\hline $\mathbf{6 . 5 0 0}$ & $31,23 \pm 3,2^{\mathrm{bc}}$ & $55,25 \pm 2,7^{\mathrm{g}}$ \\
\hline $\mathbf{7 . 3 0 0}$ & $31,52 \pm 4,4^{\mathrm{bc}}$ & $62,25 \pm 4,1^{\mathrm{f}}$ \\
\hline $\mathbf{8 . 2 0 0}$ & $31,77 \pm 3,7^{\mathrm{bc}}$ & $71,75 \pm 2,1^{\mathrm{de}}$ \\
\hline $\mathbf{9 . 1 0 0}$ & $34,28 \pm 2,4^{\mathrm{ab}}$ & $77,75 \pm 3,5^{\mathrm{cd}}$ \\
\hline $\mathbf{1 0 . 0 0 0}$ & $34,41 \pm 2,8^{\mathrm{ab}}$ & $80,5 \pm 4,2^{\mathrm{c}}$ \\
\hline $\mathbf{1 2 . 0 0 0}$ & $34,87 \pm 4,9^{\mathrm{a}}$ & $95 \pm 7,1^{\mathrm{b}}$ \\
\hline $\mathbf{1 2 . 6 0 0}$ & $36,36 \pm 2,9^{\mathrm{a}}$ & $108 \pm 4,1^{\mathrm{a}}$ \\
\hline
\end{tabular}

Keterangan: Data dianalisis menggunakan ANAVA Satu Arah dan Uji Duncan. Huruf yang berbeda pada kolom yang samamenandakan adanya perbedaan nyata $(\mathrm{p}<0,05)$.

Hasil analisis statistik Uji Jarak Berganda Duncan dengan taraf kepercayaan 95\% (Tebel 4.5) menunjukan bahwa diameter vena sentralis dosis $5.000 \mathrm{mg} / \mathrm{kg}$ BB sampai dengan dosis $12.600 \mathrm{mg} / \mathrm{kg}$ BB berpengaruh nyata dibandingkan dengan kontrol. Hal ini dapat dikatakan semakain tinggi dosis yang diberikan, maka semakain besar diameter vena sentralis yang terjadi.

Pada Tabel 4.5 menunjukkan bahwa hepatosit nekrosis perlakuan ekstrak medium oil sludge hasil fitoremediasi 30 bulan dosis 5.500 $\mathrm{mg} / \mathrm{kg}$ BB dan $6.500 \mathrm{mg} / \mathrm{kg}$ BB tidak berbeda nyata dengan kontrol (Lampiran 5). Perlakuan $7.300 \mathrm{mg} / \mathrm{kg}$ BB sampai dengan $12.600 \mathrm{mg} / \mathrm{kg}$ BB menunjukan perbedaan nyata dibandingkan dengan kontrol, Hal ini dapat diprediksi bahwa perlakuan ekstrak menggunakan dosis yang lebih tinggi dari $12.600 \mathrm{mg} / \mathrm{kg}$ BB dapat menyebabkan efek kerusakan yang lebih parah terhadap jaringan hati.

Hubungan antara dosis ekstrak medium oil sludge hasil fitoremediasi 30 bulan terhadap pelebaran diameter vena sentralis berkaitan dengan pajanan ekstrak secara oral dan sistem sirkulasi darah di hati. Menurut Lu (1995) hati merupakan organ yang sering rusak karena hati menerima $\pm 80 \%$ suplai darah dari vena porta hepatika, yang mengangkut senyawa-senyawa hasil absorbsi makanan di usus halus dan menampung zat hasil dari pencernaan yang toksik maupun nontoksik. Vena sentralis menampung darah dalam volume tinggi dari berbagai cabang sinusoid sehingga konsentrasi zat toksik yang mungkin terdapat dalam darah akan meningkat dan terakumulasi di vena sentralis (Hwang, 2011).

Adanya kandungan logam berat dalam ekstrak medium oil sludge hasil fitoremediasi 30 bulan menyebabkan sel-sel endotel dinding tunika intima vena sentralis mengalami lisis sehingga terjadi kerusakan dan pelebaran diameter vena sentralis. Menurut Khosardi, et al. (2006), pelebaran diameter vena sentralis disebabkan oleh meningkatnya aktivitas metabolik sel untuk mengekskresikan zat toksik. Oleh karena itu, diperkirakan bahwa meningkatnya dosis ekstrak medium oil sludge hasil fitoremediasi 30 bulan yang diberikan menyebabkan meningkatnya konsentrasi zat toksik dalam sirkulasi darah di hati sehingga memperparah kerusakan yang terjadi pada vena sentralis dan sel hepatosit.

Hubungan antara dosis ekstrak medium oil sludge hasil fitoremediasi 30 bulan terhadap persentase haposit nekrosis pada Tabel 4.5 menunjukan terdapat peningkatan seiring dengan kenaikan dosis, Menurut Johan., dkk (2017) Nekrosis ditandai dengan inti sel yang menjadi piknotik (tampak inti sel kecil berwarna gelap, sitoplasma sel kemerahan. dan batas tidak teratur), karioreksis (inti hancur membentuk fragmen-fragmen atau ireguler), dan akhirnya kariolisis (inti sel hilang). Adanya akumulasi zat toksik menyebabkan mitokondria terluka dan 
terjadi gangguan produksi Adenosine triphosphate (ATP), begitu juga fosforilasi oksidatif sehingga banyak ion $\mathrm{NA}^{+}$yang masuk kedalam sel hati yang mengakibatkan $\mathrm{pH}$ dalam sel menurun dan bersifat asam (Rippey, 1994).

Selain kerusakan pada vena sentralis, kerusakan lain yang teramati adalah sinusoid yang melebar. Hal ini dapat terjadi karena selsel hepatosit yang mengalami nekrosis mengakibatkan bentuk dan susunan sel menjadi tidak teratur. Menurut Johan, dkk., (2017) pelebaran sinusoid juga dapat disebabkan oleh tingginya kadar toksikan dalam darah yang mengalir melalui hati. Sinusoid merupakan kapiler darah yang membawa darah menuju vena sentralis.

Terdapat celah subendotel yang mengandung mikrovili di antara sinusoid dan sel-sel hepatosit. Celah subendotel menyebabkan terjadinya kontak langsung antara permukaan hepatosit dan sinusoid, yang memudahkan pertukaran zat-zat termasuk toksikan. Apabila konsentrasi zat toksikan dalam darah tinggi, maka kerusakan hepatosit dan sinusoid juga semakin tinggi (Junqueira, 1997). Merkuri mampu membentuk radikal bebas dalam tubuh serta menurunkan kemampuan antioksidan sehingga dengan sendirinya akan terjadinya stres oksidatif. Berbagai penelitian juga menyatakan bahwa merkuri secara langsung dapat menimbulkan terjadinya gangguan dalam proses biokimia, sistem hepatobilier dan juga dapat menyebabkan nekrosis sel hati (Suprijono 2012).

Berdasarkan data kerusakan pada jaringan hati tersebut, efek toksik berupa kerusakan histologis seperti kerusakan vena sentralis dan hepatosit nekrosis cenderung banyak ditemukan pada dosis yang lebih tinggi, hal ini dapat dikatakan bahwa pemberian dosis semakin tinggi dapat menyebabkan efek kerusakan yang lebih parah terhadap jaringan hati.

\section{SIMPULAN}

Hasil analisis probit diperoleh nilai LD50 ekstrak medium oil sludge Hasil Fitoremediasi Long Term Pada Hitologis Hati Mencit (mus musculus) adalah $16.982 \mathrm{mg} / \mathrm{kg} \mathrm{BB}$, Dalam klasifikasi toksisitas menurut Lu (2002), nilai tersebut termasuk ke dalam kategori praktis tidak toksik (>15000 mg/kg BB). Hasil pengamatan organ hati mencit dosis 12.600 $\mathrm{mg} / \mathrm{kg}$ BB mengalami peningkatan sel hepatosit nekrosis hal ini disebabkan proses fitoremedias oil sludge belum mampu mendegradasi logam berat Merkuri (Hg).

\section{UCAPAN TERIMA KASIH}

Penulis ucapakan terima kasih kepada dosen Universitas Padjadjaran Dr. Nia Rossiana, M, S, dan Dr Desak Made Malini, M.Si serta laboran yang terlibat dalam penelitian ini, atas partisipasi aktif mereka.

\section{REFERENSI}

Dellman dan Brown. 1992. Buku Teks Histologi Veteriner II Edisi 3. Penerjemah R. Hartono; Jakarta: UI Press.

Junqueira L.C., J. Carneiro, R.O. Kelley. 1997. Histologi Dasar. Ed ke-8. Tambayang J, penerjemah. Jakarta: EGC. Terjemahan dari: Basic Histology.

Liu, W., L. Yongming, T. Ying, L. Zhengao, Q.M. Lena. 2010. Bioremediation of oil sludge-contaminated soil by stimulating indigenous microbes. Environt Geochem Health. (32): 23-29.

Lu, F.C. and S. Kacew. 2002. Lu's Basic Toxicology: Fundamentals, Target Organs, and Risk Assessment. Fourth Eition. Taylor \& Francis. London.

OECD. 2001. OECD Guideline for the Testing of Chemicals, Revised Draft Test Guideline 423, Acute Oral ToxicityAcute Toxic Class Method,

Rossiana, N. T. Supriatun, dan Y. Dhahiyat. 2017. Fitoremediasi Oily Sludge Menggunakan Oil Bacter, Kascing, dan Sengon (Paraserianthes falcataria L. (Nielsen) Bermikoriza. Laporan Penelitian Hibah Kompetensi DIKTIDepdiknas. Universitas Padjadjaran. Sumedang

Pala, D., D.D. Carvalho, J.C. Pinto, G.L. Sant Anna Jr. 2006. A suitable model to describe bioremediation of a petroleumcontaminated soil. J. Int. Biodeter \& Biodegr. 58 (6): 254-260

PT. Pertamina (2001). Pedoman Pengelolaan Limbah Sludge Minyak Pada Kegiatan Operasi Pertamina. Jakarta: Pertamina

Wisse E, Braet F, Luo D et al. 1996. Structure and function of sinusoidal lining cell in the liver. Toxicol Pathol 24 (1) 